\title{
ANALISIS PENGARUH LIKUIDITAS, FAKTOR FUNDAMENTAL EKONOMI MAKRO DAN FAKTOR EKSTERNAL TERHADAP IMBAL HASIL SURAT UTANG NEGARA ( Seri FR 0031)
}

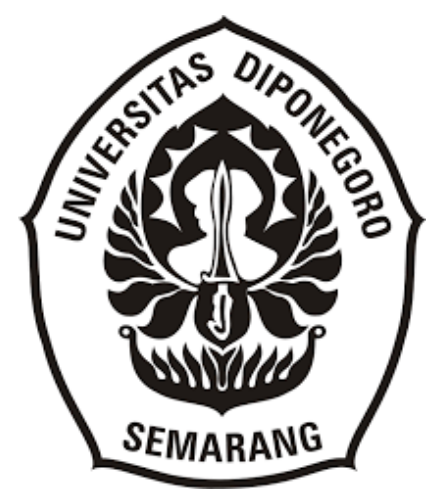

\section{SKRIPSI}

Diajukan sebagai salah satu syarat untuk menyelesaikan Program Sarjana (S1) pada Program Sarjana Fakultas Ekonomika dan Bisnis Universitas Diponegoro

Disusun oleh :

DEANDRA AULIA TIARA DEVI

NIM. 120201120061

\section{FAKULTAS EKONOMIKA DAN BISNIS UNIVERSITAS DIPONEGORO 2018}




\title{
PERSETUJUAN SKRIPSI
}

\author{
Nama Penyusun : Deandra Aulia Tiara Devi \\ Nomor Induk Mahasiswa \\ 12020114120061 \\ Fakultas / Departemen \\ : Ekonomika dan Bisnis/ Ilmu Ekonomi dan Studi \\ Pembangunan \\ Judul Skripsi

ANALISIS PENGARUH
FAKTOR FUNDITAS,
MAKRO DAN FAKTOR EKSTERNAL
TERHADAP IMBAL HASIL SURAT UTANG
NEGARA (Seri FRO031)

Dosen Pembimbing

: Prof. Dr. H. Miyasto, SU

Semarang, Desember 2018

Dosen Pembimbing,

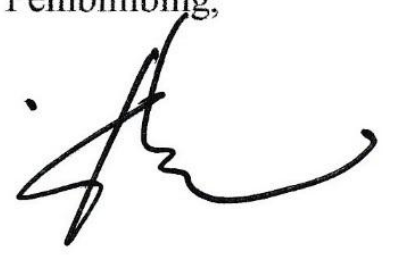

(Prof. Dr. H. Miyasto, SU )

NIP. 195012251975011001 


\section{PENGESAHAN KELULUSAN UJIAN SKRIPSI}

$\begin{array}{ll}\text { Nama Penyusun } & : \text { Deandra Aulia Tiara Devi } \\ \text { Nomor Induk Mahasiswa } & : 12020114120061 \\ \text { Fakultas / Departemen } & : \text { Ekonomika dan Bisnis/ Ilmu Ekonomi dan Studi } \\ & \text { Pembangunan } \\ & \\ \text { Judul Skripsi } & \text { :ANALISIS PENGARUH LIKUIDITAS, } \\ & \text { FAKTOR FUNDAMENTAL EKONOMI } \\ & \text { MAKRO DAN FAKTOR EKSTERNAL } \\ & \text { TERHADAP IMBAL HASIL SURAT UTANG } \\ & \text { NEGARA (Seri FR0031) }\end{array}$

Telah dinyatakan lulus ujian pada tanggal 27 Desember 2018

Tim Penguji :

1. Prof. Dr. H. Miyasto, SU.

2. Dr. Nugroho SBM, M.Si.

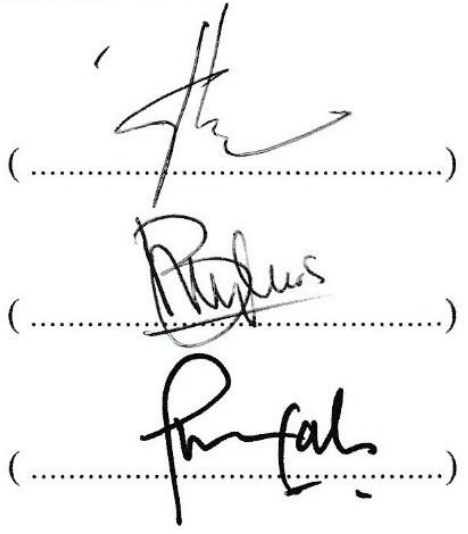

3. Firmansyah, S.E., M.Si., Ph.D.

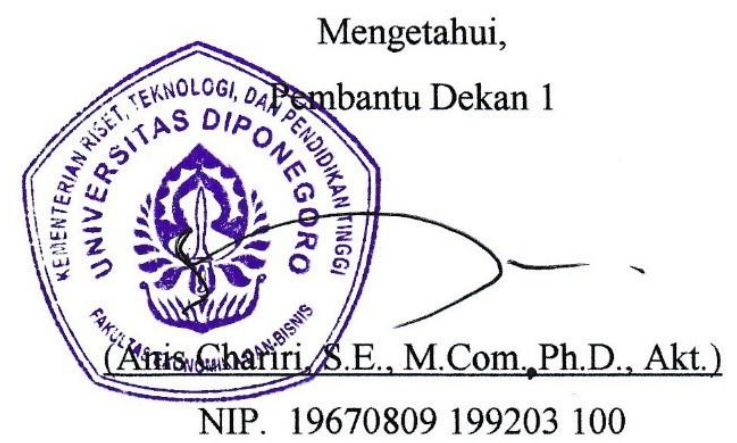




\section{PERNYATAAN ORISINALITAS SKRIPSI}

Yang bertanda tangan dibawah ini, saya Deandra Aulia Tiara Devi menyatakan bahwa skripsi dengan judul Analisis Pengaruh Likuiditas, Faktor Ekonomi Makro dan Faktor Eksternal terhadap Imbal Hasil Surat Utang Negara (Seri FR0031) adalah hasil tulisan saya sendiri. Dengan ini saya menyatakan dengan sesungguhnya bahwa dalam skripsi ini tidak terdapat keseluruhan atau sebagian tulisan orang lain yang saya ambil dengan cara menyalin atau meniru dalam bentuk rangakaian kalimat atau simbol yang menunjukkan gagasan atau pendapat atau pemikiran dari penulis lain, yang saya akui seolah-olah sebagai tulisan saya sendiri, dan/atau tidak terdapat bagian atau keseluruhan tulisan yang saya salin itu, atau yang saya ambil dari tulisan orang lain tanpa memberikan pengakuan penulis aslinya.

Apabila saya melakukan tindakan yang bertentangan dengan hal tersebut diatas, baik sengaja maupun tidak, dengan ini saya menyatakan menarik skripsi yang saya ajukan sebagai hasil tulisan saya sendiri. Bila kemudian terbukti bahwa saya melakukan tindakan menyalin atau meniru tulisan orang lain seolah-olah hasil pemikiran saya sendiri, berarti gelar dan ijazah yang telah diberikan oleh universitas batal saya terima.

Semarang, Desember 2018

Yang membuat pernyataan,

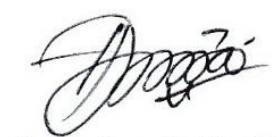

Deandra Aulia Tiara Devi

NIM 12020114120061 


\begin{abstract}
The government reopened the series FR0031 sovereign debt at the beginning of January 2010 through the Bank Indonesia auction system. The offered interest rate same as the beginning when the government issued FR0031 series debt securities, fixed rate of $11 \%$ but over time yield or yield in the form of coupons received by investors are fluctuating.

The aims of this research is to analyze the short term and long term influence of liquidity, interest rate, inflation, GDP, and exchange rate to imbal hasil National Bond (SUN) in the year of 2010 - 2017. This research using quarterly data of 2010 - 2017 for each variable. Data in this study is secondary data time series which provide by bloomberg, Bank Indonesia, BPS and publication of Directorate General of Debt Management. The methode which used in this research is Error Correction Model.

The result shows that variable inflation, GDP and exchange rate significantly positive effect in otherhand liquidity and interset rate significantly negative effect on Imbal hasil Curve SUN in long term. Judging by the value of the adjusted $R$ square was 0.906314 it means $90.63 \%$ of imbal hasil explainable by independent variables used in this research the rest $9.37 \%$ explained by other factors. Based on the regression results there is no variable that significant in the short term with $R$ square of 0.341939 which means the independent variable is able to explain $34.19 \%$ and $65.81 \%$ variation of the dependent variable
\end{abstract}

Keywords : Government Bond, Imbal hasil, ECM 


\begin{abstract}
ABSTRAK
Pemerintah melakukan reopening surat utang negara seri FR0031 pada awal bulan januari 2010 melalui sistem lelang Bank Indonesia. Tingkat bunga yang ditawarkan tetap sama seperti awal saat pemerintah menerbitkan surat utang negara seri FR0031 yaitu fixed rate sebesar $11 \%$ akan tetapi dalam berjalannya waktu yield atau imbal hasil yang berbentuk kupon yang diterima oleh para investor berfluaktif

Penelitian ini bertujuan untuk menganalisis pengaruh Likuiditas, BI Rate, Inflasi, PDB perkapita dan Nilai tukar Rupiah/dollarAS terhadap Imbal hasil Surat Utang Negara (SUN) seri FR0031 periode tahun 2010-2017 dalam jangka pendek maupun dalam jangka panjang. Penelitian ini menggunakan data kuartal sejak 2010 - 2017 untuk tiap variabel. Data dalam penelitian merupakan data sekunder yang diperoleh dari Bloomberg, Bank Indonesia, BPS dan DJPPR. Metode yang digunakan dalam penelitian ini adalah Error Correction Model (ECM).

Hasil penelitian menunjukkan bahwa variabel Inflasi, PDB perkapita dan Nilai tukar rupiah/dollarAS berpengaruh signifikan positif, namun Likuiditas dan BI rate berpengaruh negatif signifikan terhadap Imbal Hasil SUN dalam jangka panjang. Dilihat dari nilai $\mathrm{R}$ square sebesar 0.906314 yang berarti variabel independen mampu menjelaskan sebesar $90.63 \%$ dan $10.37 \%$ variasi variabel dependen. Berdasarkan hasil regresi tidak ada satupun variabel yang signifikan pada jangka pendek dengan $\mathrm{R}$ square sebesar 0.341939 yang berarti variabel independen mampu menjelaskan sebesar $34.19 \%$ dan $65.81 \%$ variasi variabel dependen.
\end{abstract}

Kata Kunci: Surat Utang Negara, Imbal hasil, ECM 


\section{MOTTO DAN PERSEMBAHAN}

"Allah tidak membebani seseorang melainkan sesuai kesanggupannya" (QS Al Baqarah: 286)

"Ingatlah Allah saat hidup tak berjalan sesuai keinginanmu. Allah pasti punya jalan terbaik untukmu"

(kutipan Berani berhijrah) 


\section{KATA PENGANTAR}

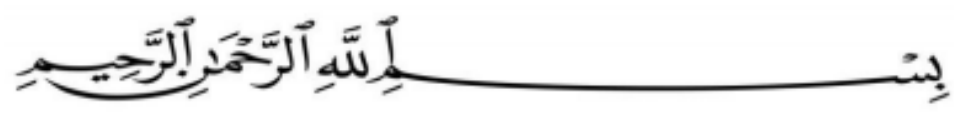

Puji dan syukur penulis panjatkan kehadirat Allah SWT karena atas rahmat dan hidayahnya serta bantuan bimbingan dari berbagai pihak, akhirnya penulis mampu menyelesaikan skripsi ini yang berjudul "Analisis Pengaruh Likuiditas, Faktor Fundamental Makroekonomi Dan Faktor Eksternal Terhadap Imbal hasil һуиииииииииииииSurat Utang Negara (Seri FR 0031)”. Skripsi ini disusun guna melengkapi persyaratan dalam menyelesaikan kelulusan tudi pada Program Sarjana (S1) Ilmu Ekonomi dan Studi Pembangunan Fakultas Ekonomika dan Bisnis Universitas Diponegoro Semarang.

Bimbingan, dorongan dan bntuan dari pengajar dan rekan-rekan serta ketulusan hati dan keramahan dari banyak pihak, sangat membantu penulis dalam penyusunan skripsi ini dengan harapan dapat mencapai hasil yang terbaik. Oleh karean itu dalam kesempatan ini perkenankanlah penulis menyampaikan ucapan terimakasih kepada :

1. Keluarga tercinta Papa, Mama, dek Ido, dek Della, Keluarga besar Sarmadi dan Soeharto yang tiada hentinya untuk memberikan doa, semangat perhatian dan motivasi yang tulus kepada penulis.

2. Prof. Dr. H. Miyasto, SU selaku Dosen Pembimbing skripsi yang telah banyak memberikan bimbingan, arahan dan motivasi dalam penyusunan skripsi. 
3. Bapak Dr. Suharnomo, S.E., M.Si., selaku Dekan Fakultas Ekonomika dan Bisnis Universitas Diponegoro.

4. Bapak Akhmad Syakir Kurnia, S.E., M.Si., Ph.D selaku Kepala Departemen Ilmu Ekonomi dan Studi Pembangunan sekaligus dosen wali yang telah memberikan nasihat dan arahan.

5. Bapak Dr. Agr. Deden Dinar Iskandar selaku dosen yang selalu menyempatkan waktunya untuk diskusi perihal skripsi ini.

6. Seluruh Dosen dan Staf Departemen Ilmu Ekonomi dan Studi Pembangunan Fakultas Ekonomika dan Bisnis Universitas Diponegoro yang telah memberikan ilmu dan bantuan kepada penulis.

7. Teman posesif Aliya, Firdha, Grace, Hilda, Lauria, Lutfiana, Nisaulfathona, Ninda, Rahmi, Yeni dan Zahrina yang telah menemani dalam proses perkuliahan dari awal hingga akhir, terimakasih atas kebersamaan, pengalaman, ilmu dan bantuan yang diberikan.

8. Teman skripsian dan diskusi yang tak ada ujungnya Dian, Erliyan, Nurmalita, Raisa, Ratih, Rahman terimakasih segala kebersamaan selama proses perkuliahan dan per skripsian.

9. Kucing garong Dinda, Fajar, Fajri, Hening dan Vega teman organisasi sekaligus travelling.

10. Semua temen-temen di Ilmu Ekonomika dan Studi Pembangunan Undip angkatan 2014 yang tidak dapat disebutkan satu persatu. Terimakasih atas kebersamaan dan pengalamannya. 
11. Teman-teman Kelompok Studi Ekonomi Islam (KSEI) periode 2015 dan 2016, Peduli Dhuafa periode 2015 dan 2016 yang mendukung, memberikan banyak pembelajaran dan bekerjasama denganbaik selama kepengurusan. KKN Desa Pundenrejo Tayu terimakasih pengalaman 42 hari yang sangat dikenang.

12. Semua pihak yang telah membantu dan teman-teman penulis lainnya yang tidak dapat diucapkan satu persatu.

Penulis menyadari skripsi ini masih ada kekurangan karena keterbatasan ilmu yang dimiliki. Namun penulis berharap skripsi ini dpat memberikan manfaat untuk berbagai pihak.

Semarang, 12 November 2018

Penulis,

Deandra Aulia Tiara Devi

NIM 12020114120061 


\section{DAFTAR ISI}

halaman

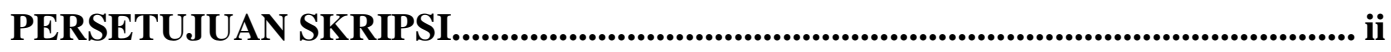

PENGESAHAN KELULUSAN UJIAN SKRIPSI ...................................................... iii

PERNYATAAN ORISINALITAS SKRIPSI ................................................................ iii

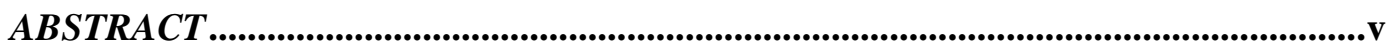

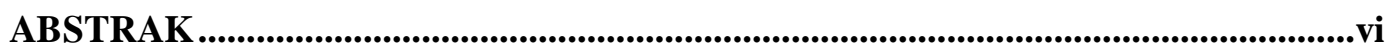

MOTTO DAN PERSEMBAHAN .............................................................................. vii

KATA PENGANTAR........................................................................................... viii

DAFTAR ISI ..................................................................................................................................xi

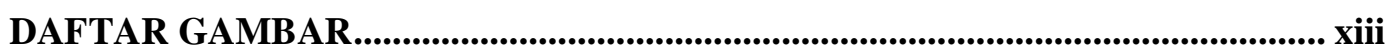

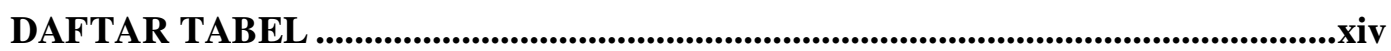

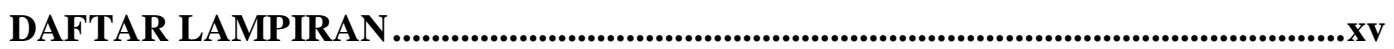

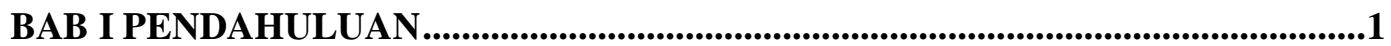

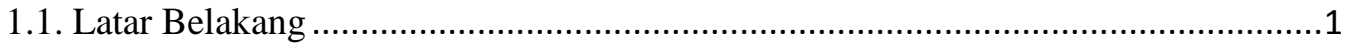

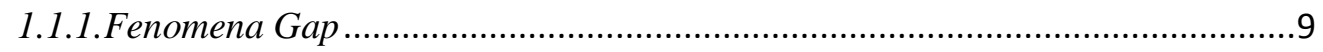

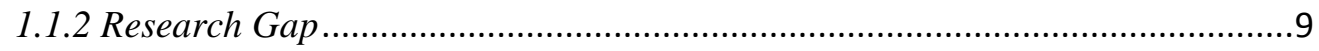

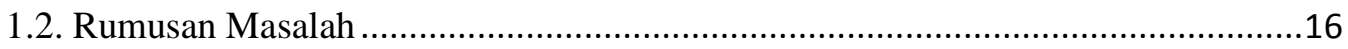

1.3. Tujuan Dan Kegunaan Penelitian ......................................................................17

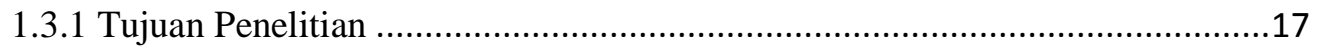

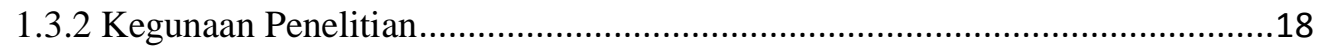

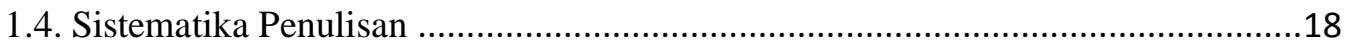

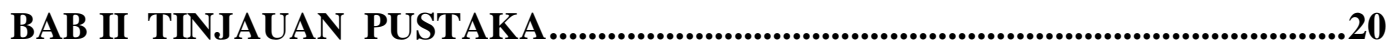

2.1. Landasan Teori Dan Penelitian Terdahulu ............................................................20

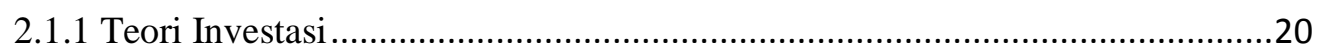

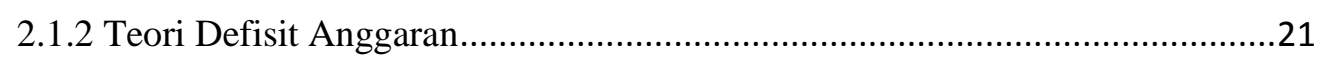

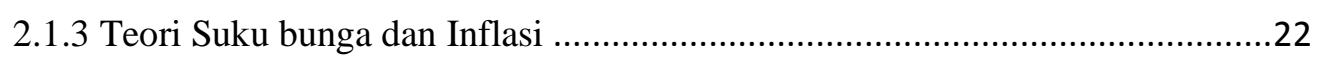

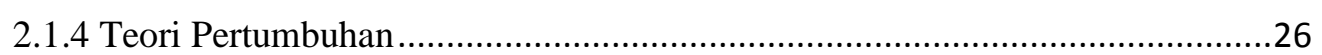

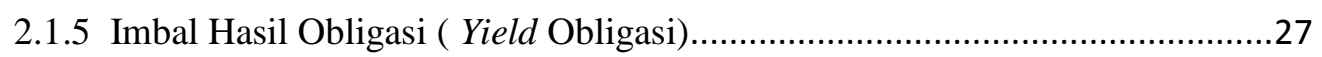

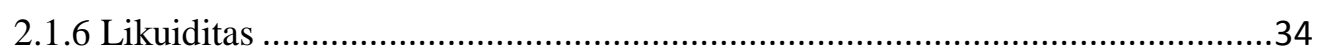

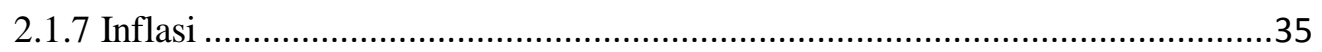

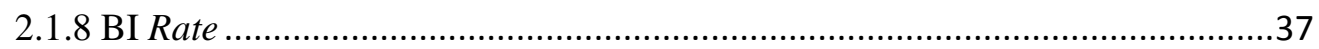




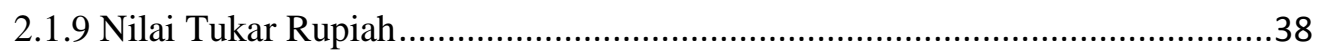

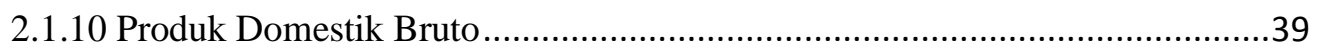

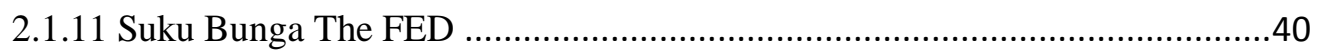

2.1.12 Teori Permintaan dan Penawaran ...............................................................4

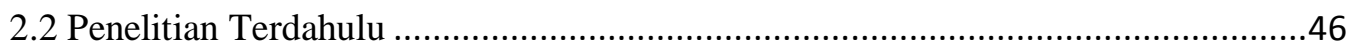

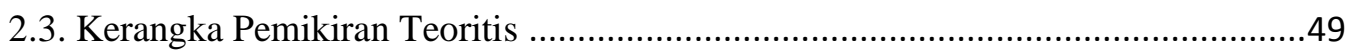

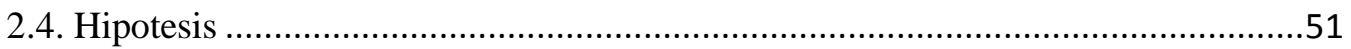

BAB III METODE PENELITIAN .......................................................................53

3.1 Variable Penelitian dan Definisi Operasional Variabel .........................................53

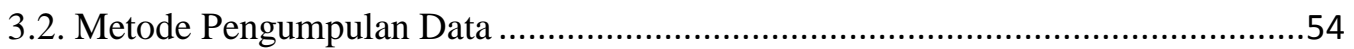

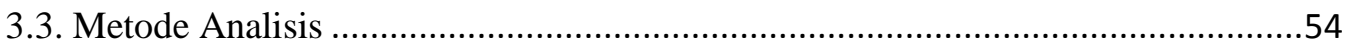

3.3.2 Deteksi Penyimpangan Asumsi Klasik.......................................................60

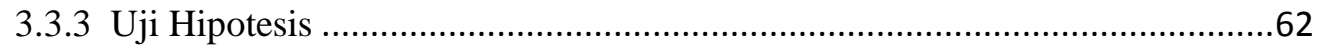

BAB IV ANALISIS HASIL DAN PEMBAHASAN ....................................................67

4.1. Deskripsi Perkembangan Variabel .......................................................................67

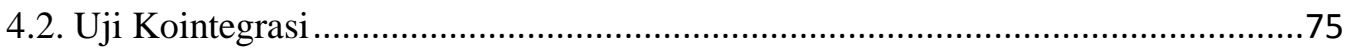

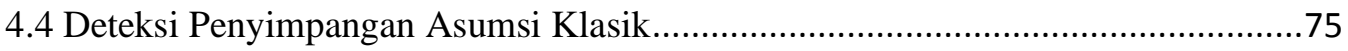

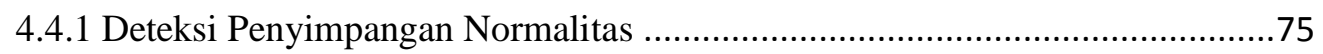

4.4.2 Deteksi Penyimpangan Autokorelasi ...........................................................76

4.4.3 Deteksi Penyimpangan Heterokedastisitas ....................................................77

4.4.4 Deteksi Penyimpangan Multikolinearitas ......................................................77

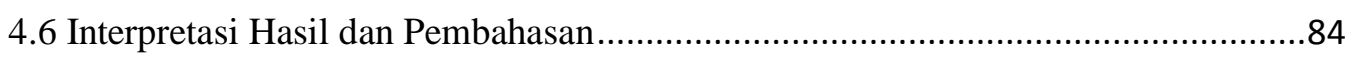

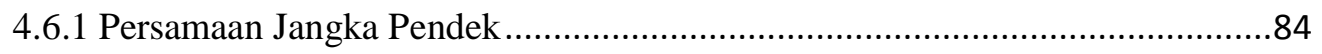

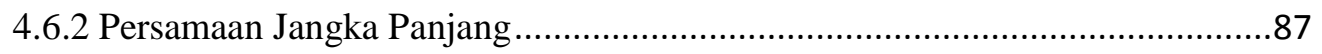

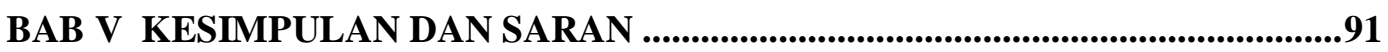

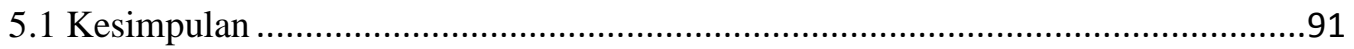

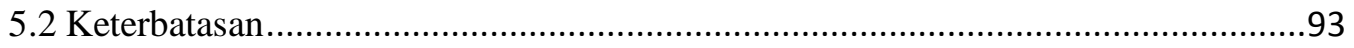

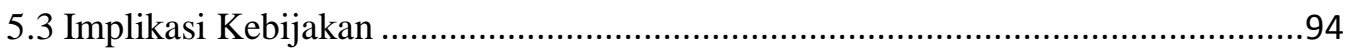

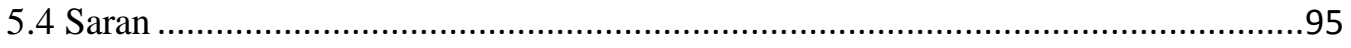

5.5 Saran penelitian yang akan datang ..................................................................96

DAFTAR PUSTAKA...................................................................................................................97

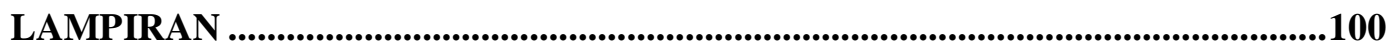




\section{DAFTAR GAMBAR}

halaman

Gambar 1. 1 Posisi Pinjaman dan Surat Berharga Negara Tahun 1998 hingga 2016

Gambar 1. 2 Proporsi Pinjaman dan Surat Berharga NegaraTahun 1998 hingga

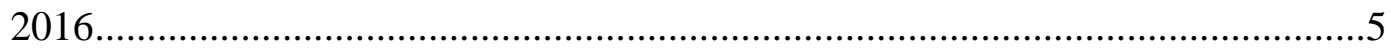

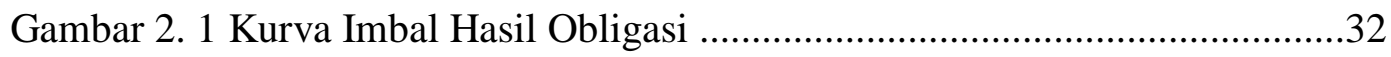

Gambar 2. 2 Grafik Permintaan dan Penawaran..................................................42

Gambar 2. 3 Kerangka Pemikiran..................................................................5 50

Gambar 4. 1 Perkembangan Imbal hasil Tahun 2008 -2017 ................................68

Gambar 4. 2 Perkembangan Likuiditas 2008 - 2017 .........................................69

Gambar 4. 3 Perkembangan Inflasi dan IHK tahun 2005 - 2017 ..........................70

Gambar 4. 4 Perkembangan Inflasi Tahun 2008 - 2017 ......................................70

Gambar 4. 5 Perkembangan BI Rate Tahun 2008 - 2017 ....................................71

Gambar 4. 6 Perkembangan Nilai Tukar Rupiah/Dollar AS Tahun 2008 - 2017..72

Gambar 4. 7 Perkembangan PDB Tahun 2008 - 2017...........................................73

Gambar 4. 8 Perkembangan Suku Bunga The FED tahun 2008 - 2017 ................74

Gambar 4. 9 Q-Q Plot Jangka Pendek .............................................................76

Gambar 4. 10 Q-Q Plot JangkaPanjang ........................................................76 


\section{DAFTAR TABEL}

halaman

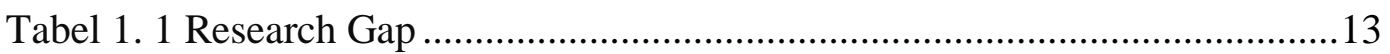

Tabel 2. 1 Faktor-Faktor yang Menggeser Kurva Permintaan Obligasi ................44

Tabel 2. 2 Faktor-Faktor yang Menggeser Kurva Penawaran Obligasi.................46

Tabel 2. 3 Penelitian Terdahulu ................................................................... 47

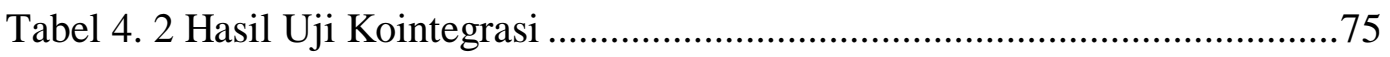

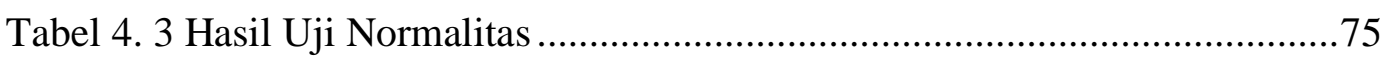

Tabel 4. 4 Hasil Uji Breusch Godfrey .............................................................. 77

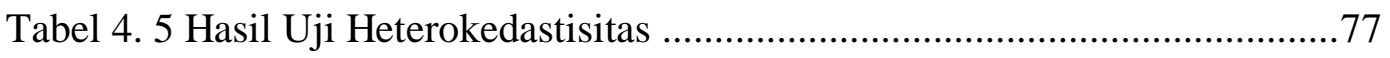

Tabel 4. 6 Hasil Uji Variance Inflation Factor ................................................... 78

Tabel 4. 7 Hasil Uji Correlation Jangka Panjang................................................78

Tabel 4. 8 Hasil Uji Correlation Jangka Pendek.................................................78

Tabel 4. 9 Hasil Regresi dalam Jangka Panjang .................................................79

Tabel 4. 10 Hasil Regresi dalam Jangka Pendek ...................................................79

Tabel 4. 11 Nilai t-statistik Persamaan Jangka Panjang .....................................82

Tabel 4. 12 Nilai t-statistik Persamaan Jangka Pendek .........................................8 82 


\section{DAFTAR LAMPIRAN}

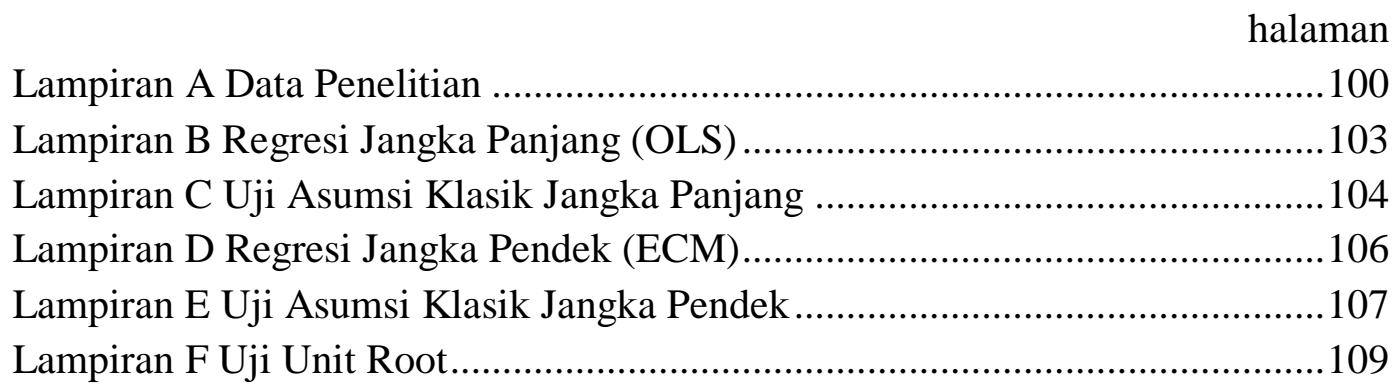




\section{BAB I \\ PENDAHULUAN}

\subsection{Latar Belakang}

Dalam suatu perekonomian, pemerintah memiliki peran yang sangat penting dalam mengatasi masalah pengangguran, menghindari inflasi, dan mempercepat pembangunan ekonomi dalam jangka panjang. Kebijakan Fiskal umumnya merepresentasikan pihan-pilihan pemerintah dalam menentukan besarnya jumlah pengeluaran atau belanja dan jumlah pendapatan, yang secara eksplisit digunakan untuk mempengaruhi perekonomian. Adakalanya pemerintah sengaja menciptakan defisit dalam anggaranya (pemerintah membuat pos belanja negara lebih besar dari pendapatan negara), pemerintah menempuh kebijakan defisit anggaran karena ingin menjaga momentum serta melihat adanya potensi untuk meningkatkan pertumbuhan ekonomi melalui pemberian stimulus fiskal secara terukur dengan tetap menjaga kesinambungan fiskal. Tujuan yang diharapkan dari anggaran ekspansi adalah peningkatan pertumbuhan ekonomi bangsa yang dapat meningkatkan kesejahteraan masyarakat.

Penerapan anggaran defisit juga berdampak pada kebutuhan pemerintah dalam menyediakan dana untuk menutupi selisih pendapatan dan anggaran belanja negara yang ada. Dalam Undang-undang Nomor 17 tahun 2003 tentang Keuangan Negara pasal 12 ayat (3) disebutkan bahwa dalam hal anggaran diperkirakan defisit, ditetapkan sumber-sumber pembiayaan untuk menutup defisit tersebut dalam Undang-undang tentang APBN. Defisit anggaran dibatasi maksimal 3 persen terhadap Produk Domestik Bruto. Defisit itu merupakan gabungan antara defisit 
pemerintah pusat dengan pemerintah daerah. Sementara rasio utang dibatasi maksimal 60 persen terhadap Produk Domestik Bruto. Pembiayaan atas pembelanjaan defisit oleh Pemerintah ditutup dengan pinjaman (utang) pemerintah baik jangka panjang maupun jangka pendek, baik dari dalam maupun dari luar negeri. Pemerintah mengoptimalkan sumber-sumber pembiayaan utang dalam negeri yang dilaksanakan bersamaan dengan upaya mengoptimalkan peran serta dari masyarakat (financial inclusion), mengembangkan pasar keuangan domestik dan meningkatkan efek multiplier perekonomian nasional (DJPU, 2010).

Pengelolaan utang yang tidak prudent dapat menimbulkan permasalahan yang fatal bagi keuangan negara. Indonesia dapat mengambil pelajaran penting dari Amerika Serikat dan Uni Eropa. Krisis ekonomi yang terjadi di kedua kawasan tersebut berakar dari penggunaan dan pengelolaan utang yang tidak hati-hati. Tingginya utang Amerika Serikat akibat mendanai perang di Irak dan Afghanistan yang terus membengkak berpotensi mengganggu daya fiskal ketika terjadi tekanan eksternal seperti krisis 2008. Krisis ini berawal pada tahun 2001 - 2005, pertumbuhan perumahan di Amerika Serikat menggelembung dikarenakan The FED menurunkan suku bunga sehingga dimanfaatkan oleh pengembang dan perusahaan pembiayaan perumahan untuk membangun rumah murah dengan skema subprime. Disini subprime lenders (lembaga pembiayaan perumahan) mengumpulkan berbagai utang itu dan mejualnya kepada bank komersial, oleh bank komersial sebagai portofolio tersebut dijual lagi kepada bank investasi. Bank investasi lalu menjual kembali kepada investor di seluruh dunia seperti bank komersial, perusahaan asuransi, maupun investor perorangan. Kumpulan utang 
tersebut dinamakan Mortgage-Backed Securities (MBS) yang merupakan bentuk utang yang dijamin. MBS ini termasuk salah satu bentuk transaksi derivatif yang penuh resiko.

Pada tahun 2007, ketika koreksi pasar menyebabkan penurunan nilai rumah-rumah hingga miliaran dollar AS, sebanyak 2,5 juta warga AS yang membeli rumah tidak mampu membayar cicilan. Ketika ini terjadi, satu-satunya jaminan bagi MBS adalah rumah-rumah itu sendiri, akan tetapi karena penawaran melebihi permintaan seiring dengan pertumbuhan industri perumahan dalam kurun waktu 2001 hingga 2005 maka nilai rumah-rumah itupun turun dan tidak sesuai dengan nilai yang dijaminkan dalam MBS. Sementara bank investasi harus tetap memberi pendapatan berupa bunga kepada para investornya. Inilah asal mula terjadinya krisis subprime mortage yang berimbas ke seluruh dunia. Pemilik surat utang Subprime Mortage bukan hanya pernabkan di Amerika Serikat, tetapi juga perbankan di Autralia, Tiongkok, India, Taiwan dan negara-negara lainnya. Dampaknya harga saham perbankan diseluruh dunia jatuh, termasuk Indonesia meskipun sejauh ini perbankan Indonesia tidak memiliki surat utang Subprime Mortage, akan tetapi karena harga saham perbankan di negara tetangga jatuh investor asing juga menjual saham perbankan dan nonperbankan di Indonesia. Inilah yang menyebabkan harga saham turun, imbal hasil obligasi naik (harga turun) dan kurs rupiah melemah.

Seperti halnya di Amerika Serikat kawasan Uni Eropa juga memiliki tingkat utang pemerintah yang cukup tinggi. Sehingga pemerintah kawasan Uni Eropa harus mengeluarkan dana cukup besar untuk menalangi perbankan dan lembaga 
keuangannya agar tidak terjadi pembekuan terhadap sistem kredit secara masif. Dimulai dari Yunani, sebnayak 17 negara pengguna mata uang Euro pun akhirnya ikut terseret dalam jebakan utang, yakni dengan tingkat yang sudah sangat mengkhawatirkan, yakni diatas 80 persen dari produk domestik bruto (PDB). Yunani, Italia, dan Portugal bahkan sudah berada di atas 100 persen dari PDB.

Indonesia juga pernah mengalami kejadian serupa , dimana utang yang tidak prudent yang telah menjadi pemicu krisis moneter 1998 yang berkepanjangan. Krisis ini dipicu oleh penurunan nilai mata uang regional dan domestik. Pada pemerintahan era orde baru pemerintah lebih banyak menggunakan pinjaman luar negeri sebagai instrumen untuk membiayai defisit anggaran. Kebijakan yang diambil tersebut memiliki resiko yang tinggi karena berkaitan dengan nilai tukar, dimana ketika nilai uang rupiah turun terhadap mata uang negara lain maka akan berkaitan dengan jumlah terhutang yang akan dibayar ketika jatuh tempo. Krisis ekonomi tahun 1997-1998 menjadi pembelajaran yang terbaik bagi pengelolaan utang pemerintah, dimana ketika nilai Rupiah terdepresiasi terhadap nilai US Dollar yang berakibat pada pembekakan utang menjadi berlipat ganda. Oleh karena itu sejak tahun 2000, pemerintah memilih untuk melakukan pembiayaan melalui sumber-sumber yang ada di dalam negeri melalui obligasi.

Obligasi pemerintah merupakan bagian dari Surat Utang Negara (SUN) yang diterbitkan oleh pemerintah. Obligasi dipilih karena dipandang memiliki default risk yang lebih rendah jika dibandingkan dengan obligasi korporasi sehingga menarik para investor untuk menjadikan obligasi sebagai salah satu komponen asetnya. Surat Utang Negara dapat membantu pemerintah untuk 
meningkatkan dan memperbaiki stabilitas sistem keuangan serta menyediakan pembiayaan jangka panjang bagi proyek-proyek infrastruktur.

\section{Gambar 1.1}

Posisi Pinjaman dan Surat Berharga Negara Tahun 1998 hingga 2016
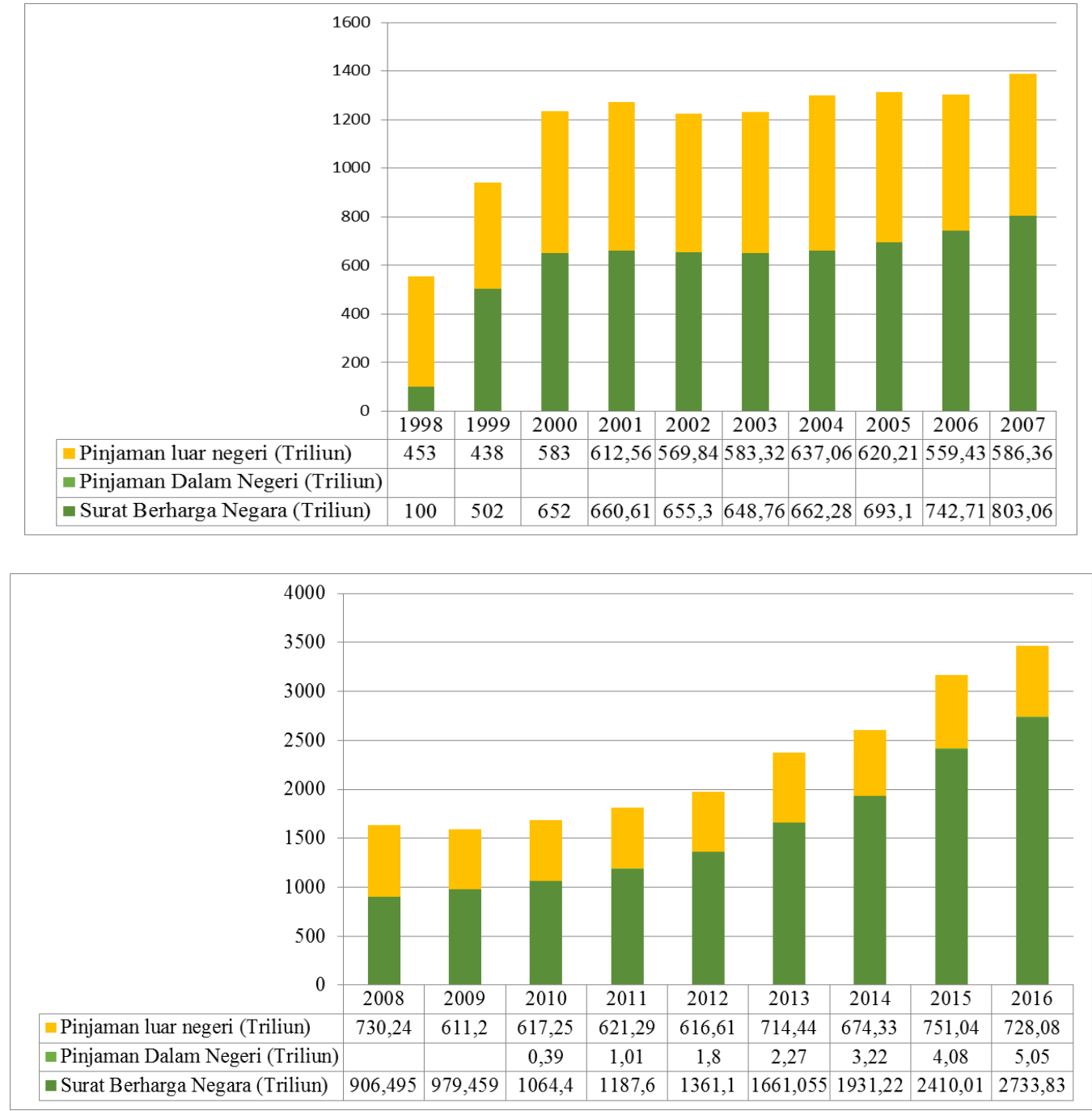

Sumber : Publikasi DJPU Kementrian Keuangan ( diolah )

\section{Gambar 1. 2}

Proporsi Pinjaman dan Surat Berharga NegaraTahun 1998 hingga 2016 


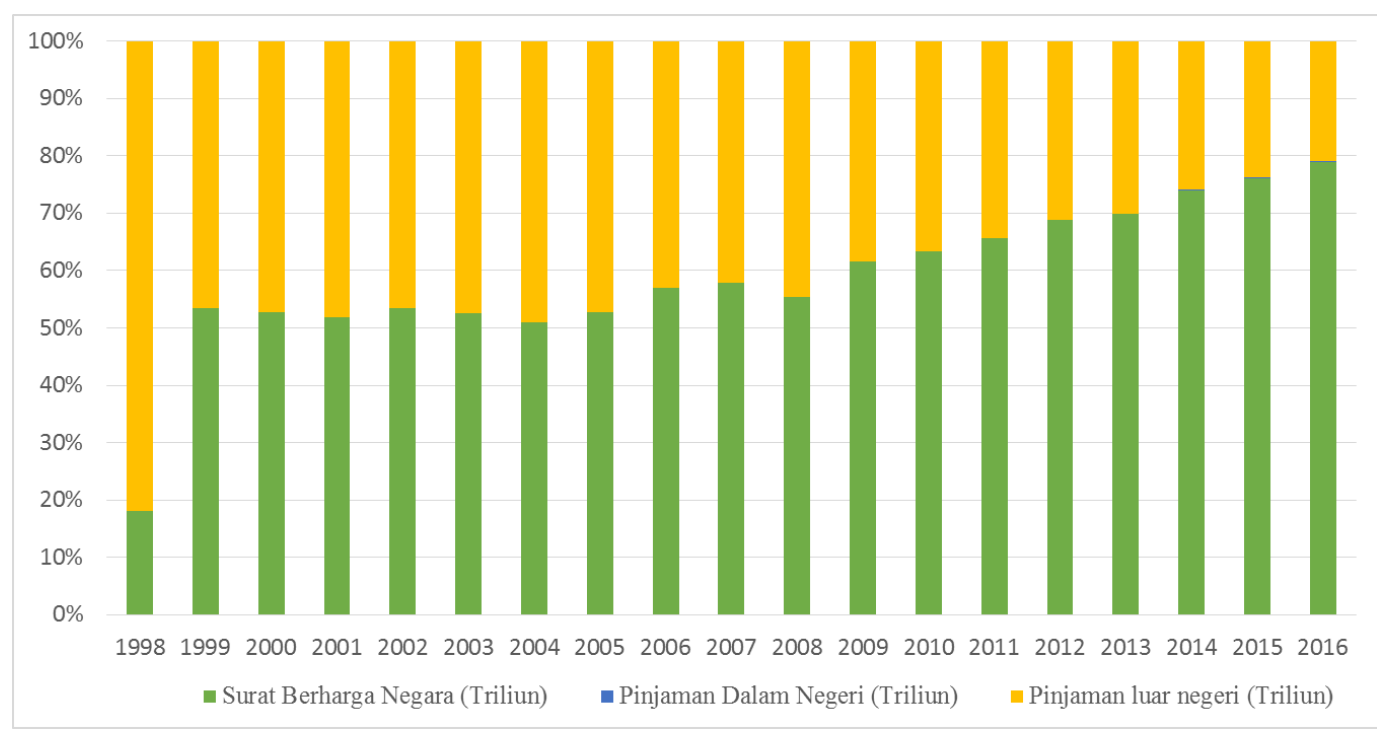

Sumber : Publikasi DJPU Kementrian Keuangan (diolah)

Gambar 1.1 dan Gambar 1.2 menunjukkan pemerintah Indonesia berupaya untuk terus merestrukturisasi utangnya kedalam bentuk Surat Berharga Negara (SBN). Restrukturisasi utang pemerintah diperlukan untuk mengurangi ketergantungan terhadap negara donor atau instansi atau lembaga donor tertentu. Apabila bentuk utang pemerintah adalah pinjaman, maka persyaratan atas pemberian utang yang ditentukan oleh negara pendonor dipandang tidak menguntungkan (selain terikat dengan persyaratan yang bersifat politis, pinjaman luar negeri terikat oleh jangka waktu utang, tingkat suku bunga dan besarnya cicilan yang harus dibayar oleh pemerintah Indonesia). Tetapi ketika struktur utang dalam bentuk obligasi (securities), maka dependensi pemerintah terhadap negara- negara dan instansi atau lembaga pendonor (pemberi pinjaman) dapat diminimalkan.

Berdasarkan data publikasi DJPU Kemenkeu pada tahun 2016, menunjukan pada bulan Desember 2016 proporsi utang pemerintah Indonesia dalam bentuk Surat Berharga Negara (SBN) sebesar 76\% sedangkan pinjaman luar negeri dan 
dalam negeri sebesar 24\%. Jangka waktu pinjaman (tenor) obligasi (securities) dapat ditentukan sendiri oleh pemerintah bebas dari intervensi pihak manapun. Sehingga dapat disesuaikan dengan kebutuhan likuiditas jangka pendek, jangka menengah maupun jangka panjang, ditinjau dari segi likuiditas, jelas bahwa obligasi pemerintah lebih likuid dibandingkan dengan obligasi korporasi. Hal ini nampak dari selalu terdapat kuotasi harga atas berbagai jenis obligasi pemerintah setiap hari di pasar. Sehingga lembaga keuangan baik bank maupun non-bank menjadikan obligasi sebagai secondary reserve. Peningkatan volume transaksi SBN merupakan hal yang positif bagi pasar keuangan Indonesia, SBN ( Surat Berharga Negara ) merupakan instrumen yang dinilai bebas resiko dan juga menjadi acuan dalam bunga obligasi korporasi. Oleh karena itu perdagangan SBN menjadi perhatian investor tidak hanya domestik namun juga investor asing. Tingkat keuntungan atau imbal hasil yang diberikan pemerintah Indonesia relatif lebih tinggi dibandingkan obligasi pemerintah negara tetangga kawasan Asia, sehingga hal ini cukup menarik bagi para investor.

Tujuan utama investor memilih investasi obligasi adalah imbal hasil. Imbal hasil dapat memberikan informasi mengenai keuntungan dari dana yang akan diinvestasikan melalui obligasi. Mengingat besarnya proporsi obligasi negara dan diperdagangkan di pasar sekunder dimana tujuan investasinya adalah imbal hasil. Para investor dan pelaku pasar untuk dapat memantau perkembangan nilai portofolio obligasi pemerintah yaitu dengan memantau perkembangan pergerakan imbal hasil curve. Para investor obligasi menggunakan imbal hasil curve sebagai acuan dalam meramalkan tingkat suku bunga, menetapkan harga obligasi dan 
menetapkan strategi untuk meningkatkan keuntungan mereka. Pergerakan imbal hasil curve dipengaruhi oleh perubahan imbal hasil obligasi yang menjadi kontributor sebagai akibat adanya perubahan variabel makro ekonomi. Dengan demikian analisa perubahan variabel-variabel makro ekonomi terhadap imbal hasil obligasi pemerintah menjadi hal yang penting untuk dipahami oleh para investor dan pelaku pasar. Sementara pemerintah dalam hal ini menetukan kebijakan moneter menggunakan imbal hasil curve dalam merumuskan kebijakan yingkat suku bunga, penargetan inflasi dan menjaga pertumbuhan ekonomi berkelanjutan.

Analisa terhadap pergeseran imbal hasil curve yang menunjukkan imbal hasil obligasi pada berbagai tahun jatuh tempo menjadi hal yang penting untuk dipahami oleh para investor dan pelaku pasar. Dimana pergeseran imbal hasil curve amat dipengaruhi oleh salah satu komponen utamanya yaitu imbal hasil Obligasi Benchmark pemerintah. Sehingga dengan diketahui faktor-faktor yang memiliki determinan terhadap imbal hasil obligasi benchmark pemerintah. Memantau perkembangan nilai portofolio obligasi pemerintah yang dimiliki serta sebagai pedoman bagi pemerintah untuk melakukan ekspansi di pasar obligasi domestik maupun ke pasar obligasi internasional. Terlebih pergerakan imbal hasil curve akan berdampak pada beban bunga yang harus dibayar pemerintah atas obligasi yang diterbitkan. Meskipun pasar obligasi pemerintah Indonesia telah berkembang sedemikian pesat, namun penelitian mengenai imbal hasil Surat Utang Negara (SUN) masih jarang ditemui. Hal semacam ini tidak hanya ditemui di Indonesia saja akan tetapi juga banyak ditemui dinegara berkembang lainnya, Min (1998). Berdasarkan latar belakang dan pertimbangan di atas, maka tertarik penelitian ini 
mengambil topik " Analisis Pengaruh Likuiditas, Fundamental Ekonomi Makro dan Faktor Eksternal terhadap Imbal Hasil Surat Utang Negara (Seri FR 0031)".

\subsubsection{Fenomena Gap}

Pemerintah melakukan reopening surat utang negara seri FR0031 pada awal bulan januari 2010 melalui sistem lelang Bank Indonesia. Tingkat bunga yang ditawarkan tetap sama seperti awal saat pemerintah menerbitkan surat utang negara seri FR0031 yaitu fixed rate sebesar 11\% akan tetapi dalam berjalannya waktu yield atau imbal hasil yang berbentuk kupon yang diterima oleh para investor berfluaktif. Imbal hasil obligasi sangat bergantung pada harga obligasi. Harga obligasi sendiri sangat bergantung pada banyak faktor selain faktor permintaan dan penawaran, kondisi makro ekonomi dan tren suku bunga domestik dan luar negri juga sangat mempengaruhi pergerakan harga obligasi di pasar.

\subsubsection{Research Gap}

Ketika melakukan investasi berupa obligasi, pendapatan berupa kupon (bunga) dan imbal hasil hanya diperoleh apabila obligasi tersebut dipegang hingga waktu jatuh tempo. Namun jika obligasi tersebut dijual sebelum waktu jatuh tempo, maka harga dari obligasi pada saat dijual kembali ditentukan dari imbal hasil nya, maka salah satu faktor penting yang harus diperhatikan investor sebelum berinvestasi dalam obligasi adalah imbal hasil. Hubungan antara imbal hasil dengan waktu jatuh tempo tertentu adalah struktur jangka waktu tingkat bunga yang digambarkan melalui imbal hasil. Untuk mengetahui imbal hasil pada masa yang akan datang dibutuhkan suatu metode peramalan. Berdasarakan perilaku investor 
yang mempertimbangkan imbal hasil sebagai faktor penting sebelum berinvestasi maka membutuhkan penelitian yang lebih lanjut tentang faktor-faktor apa saja yang mempengaruhi imbal hasil.

Penelitian yang dilakukan oleh Nurfauziah dan Adistien (2004) yang menemukan hasil bahwa tingkat suku bunga tidak berpengaruh signifikan terhadap imbal hasil obligasi, begitu juga dengan hasil penelitian yang dilakukan oleh Thompson dan Vaz (1990). Berbeda dengan penelitian yang dilakukan oleh Kadir (2007), Surya dan Nasher (2011) serta Noviana (2012) yang menunjukkan hasil bahwa terdapat pengaruh positif dan signifikan antara tingkat suku bunga terhadap tingkat imbal hasil obligasi, hasil penelitian yang sama juga dikemukakan dalam penelitian yang dilakukan oleh Wibisono (2010). Prastowo (2008) dan Krisnilasari (2007) menemukan bahwa imbal hasil obligasi secara konsisten memberikan respon positif dan signifikan terhadap perubahan BI rate.

Penelitian yang dilakukan oleh Nurfauziah dan Adistien (2004) menemukan bahwa inflasi berpengaruh positif dan signifikan terhadap imbal hasil obligasi, begitu juga penelitian yang dihasilkan Baele et al. (2007) mengatakan bahwa adanya pergerakan return obligasi dan saham disebabkan oleh faktor tingkat bunga dan inflasi sementara Campbell \& Ammer (1993) mengungkapkan bahwa pengumuman mengenai inflasi kedepan merupakan faktor yang mempengaruhi pergerakan imbal hasil obligasi dalam jangka panjang. Orlowski dan Kristen (2005) menemukan bahwa inflasi memiliki pengaruh positif pada imbal hasil obligasi pemerintah Ceko dan Hungaria, namun berbeda dengan penelitian Sam'ani (2009) menyatakan bahwa inflasi tidak secara signifikan berpengaruh terhadap imbal hasil 
obligasi. Perovic (2015) yang menguji 10 negara CEE (Central and Eastern European) menunjukkan bahwa inflasi memiliki pengaruh negative signifikan terhadap imbal hasil obligasi.

Penelitian yang dilakukan oleh Muharam (2011) menemukan ketika peningkatan likuiditas diikuiti dengan penurunan imbal hasil obligasi begitu pula sebaliknya. Jacobs, et al. (2011) menujukkan presentase perubahan foreign reserves mempengaruhi secara negative terhadap imbal hasil sovereign global bond. Berbeda dengan hasil penelitian Idham (2014) yang menunjukkan kondisi likuiditas suatu perekonomian melalui peningkatan likuiditas akan direspon positif oleh imbal hasil obligasi.

Penelitian yang dilakukan oleh Gadanecz, et al (2014) menemukan pengaruh penting dari resiko nilai tukar ketika volatilitas meningkat, investor membutuhkan kompensasi imbal hasil yang lebih besar dalam memegang local currency sovereign bond pada 20 negara EME (Emerging Market Economies), begitu juga dengan hasil yang ditunjukkan oleh Wibisono (2010) bahwa nilai tukar berpengaruh positif terhadap imbal hasil, ketika depresiasi nilai tukar Rupiah terhadap US Dollar akan membuat investor menginginkan imbal hasil yang lebih tinggi. Berbeda dengan penelitian Yu Hsing (2015) pada imbal hasil obligasi pemerintah Spanyol menemukan bahwa nilai tukar nominal berpengaruh negatif terhadap imbal hasil.

Penelitian yang dipublikasikan oleh Nurul Fitriani (2014) mengemukaan penurunan imbal hasil SUN benchmark Indonesia dipengaruhi oleh imbal hasil obligasi Pemerintah Amerika, terdapat korelasi positif diantara kedua imbal hasil 
tersebut. Arah gerakan imbal hasil obligasi Pemerintah Amerika Serikat (AS) sejalan dengan imbal hasil SUN Indonesia dalam artian ketika US treasury naik maka imbal hasil SUN Indonesia juga akan naik meskipun kenaikannya tidak setinggi US treasury. Kebijakan Federal Reserve dalam menentukan suku bunga acuan sangat mempengaruhi imbal hasil SUN Indonesia, begitu juga dengan hasil yang ditunjukkan oleh Fiki Ariyati dan Schneider (2017) bahwa ketika Federal Reserve menaikan suku bunga acuan maka kebijakan itu akan mendorong penguatan dolar AS yang akan berdampak pada pembengkakan biaya utang akibat kenaikan tingkat bunga (imbal hasil). Dampaknya ke kurs rupiah karena pelemahan rupiah akan berpengaruh negative terhadap imbal hasil SUN. 
Tabel 1. 1 Research Gap

\begin{tabular}{|c|c|c|c|c|}
\hline NO & $\begin{array}{c}\text { Permasalahan } \\
\text { Penelitan }\end{array}$ & $\begin{array}{c}\text { Research } \\
\text { Gap }\end{array}$ & Penelitian & Judul \\
\hline 1 & Inflasi & $\begin{array}{l}\text { Inflasi } \\
\text { berpengaruh } \\
\text { positif } \\
\text { signifikan } \\
\text { terhadap } \\
\text { Imbal hasil } \\
\text { Obligasi }\end{array}$ & $\begin{array}{l}\text { 1. Nurfauziah } \\
\text { dan Adistien } \\
\text { (2004) } \\
\text { 2. Baele et al. } \\
\text { (2007) } \\
\text { 3. Campbell } \\
\text { dan Ammer } \\
\text { (1993) } \\
\\
\text { 4. Orlowski dan } \\
\text { Kirsten } \\
\text { (2005) }\end{array}$ & $\begin{array}{l}\text { Analisis Faktor-faktor } \\
\text { yang mempengaruhi } \\
\text { Imbal hasil Obligasi } \\
\text { Perusahaan (studi } \\
\text { kasus pada industry } \\
\text { perbankan dan } \\
\text { finansial } \\
\text { The Determinants of } \\
\text { Stock and Bond Return } \\
\text { Comovents } \\
\text { What Moves the Stock } \\
\text { and Bond Markets ? } \\
\text { Avariance } \\
\text { Decomposition for } \\
\text { Long Term Asset } \\
\text { Returns } \\
\text { Bond Imbal hasil } \\
\text { Compression in the } \\
\text { Countries Converging } \\
\text { to the Euro }\end{array}$ \\
\hline & & $\begin{array}{l}\text { Inflasi } \\
\text { berpengaruh } \\
\text { negative } \\
\text { signifikan } \\
\text { terhadap } \\
\text { Imbal hasil } \\
\text { Obligasi }\end{array}$ & $\begin{array}{l}\text { 1. Sam'ani } \\
\text { (2009) } \\
\\
\text { 2. Perovic } \\
\text { (2015) }\end{array}$ & $\begin{array}{l}\text { Pengaruh Bunga } \\
\text { Pasar, Jatuh Tempo } \\
\text { Obligasi, Rating } \\
\text { Obligasi, Nilai tukar } \\
\text { dan Inflasi terhadap } \\
\text { Imbal hasil Obligasi di } \\
\text { BEI } \\
\text { The Impact of Fiscal } \\
\text { Positions on } \\
\text { Government Bond } \\
\text { Imbal hasils in CEE } \\
\text { Countries }\end{array}$ \\
\hline
\end{tabular}


Tabel 1.1 Lanjutan

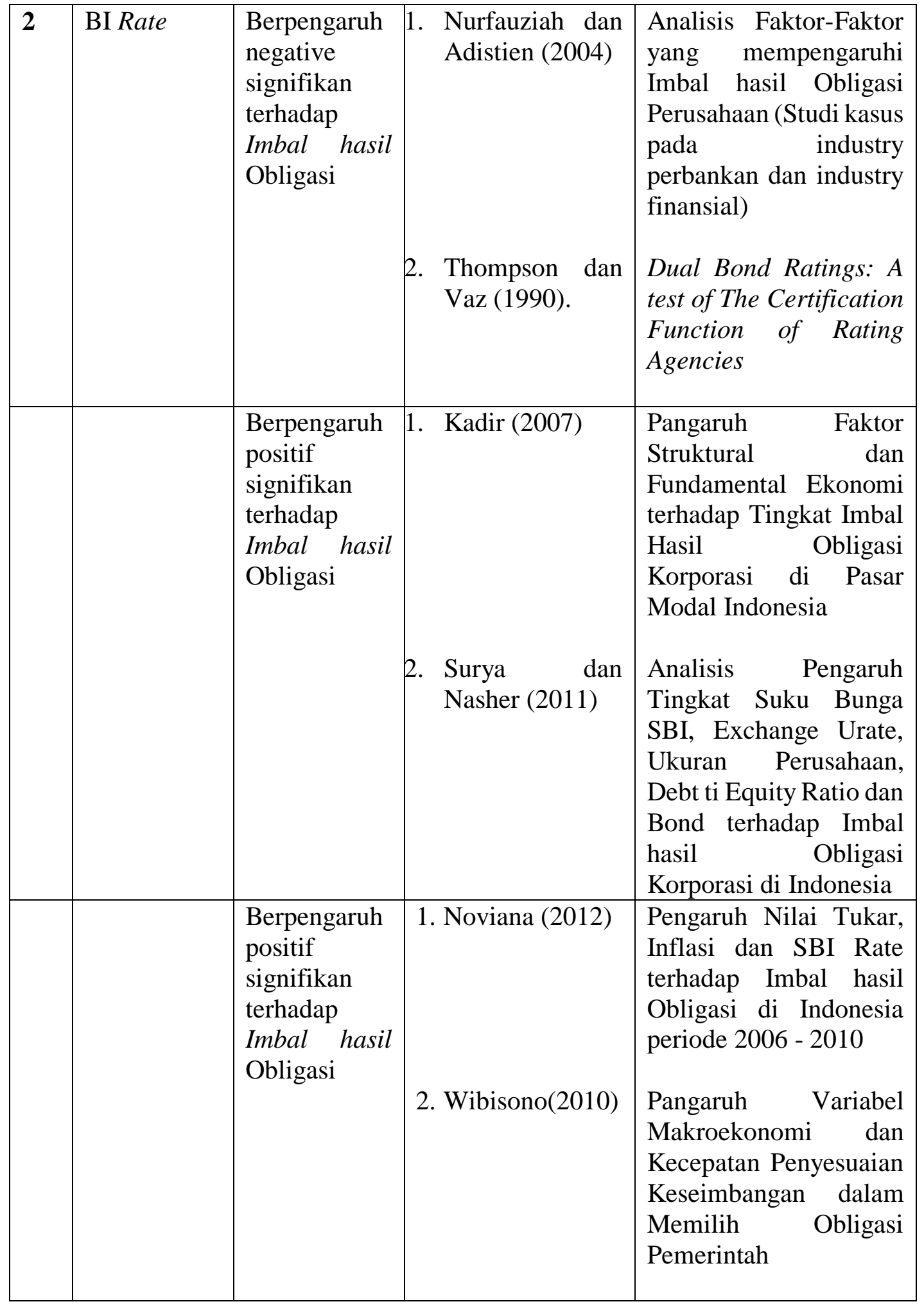


Tabel 1.1 Lanjutan

\begin{tabular}{|c|c|c|c|c|}
\hline & & $\begin{array}{l}\text { Berpengaruh } \\
\text { positif } \\
\text { signifikan } \\
\text { terhadap } \\
\text { Imbal hasil } \\
\text { Obligasi }\end{array}$ & $\begin{array}{l}\text { 4.Krisnilasari } \\
\text { (2007) }\end{array}$ & 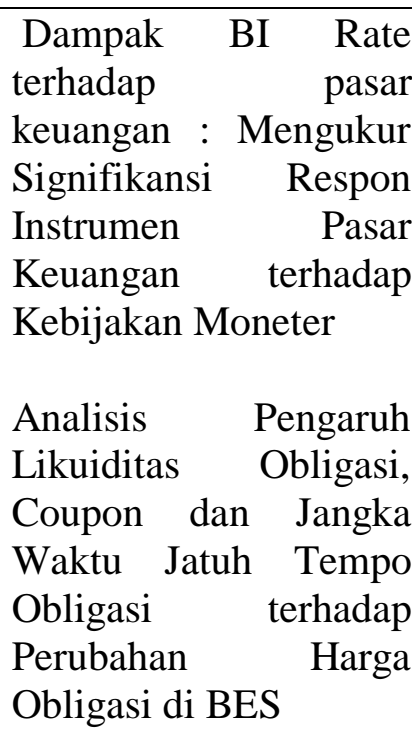 \\
\hline 3 & $\begin{array}{l}\text { Nilai Tukar } \\
\text { Rupiah } \\
\text { terhadap } \\
\text { Dollar }\end{array}$ & $\begin{array}{l}\text { Nilai tukar } \\
\text { berpengaruh } \\
\text { positif } \\
\text { signifikan } \\
\text { terhadap } \\
\text { Imbal hasil } \\
\text { Obligasi }\end{array}$ & $\begin{array}{l}\text { 1. Gadanecz, et al } \\
\text { (2014) } \\
\text { 2. Wibisono } \\
(2010)\end{array}$ & $\begin{array}{l}\text { Exchange Rate Risk and } \\
\text { Local Currency } \\
\begin{array}{l}\text { Sovereign Bond Imbal } \\
\text { hasil in Emerging } \\
\text { Market }\end{array} \\
\text { Pangaruh Variabel } \\
\text { Makroekonomi dan } \\
\text { Kecepatan Penyesuaian } \\
\text { Keseimbangan dalam } \\
\text { Memilih Obligasi } \\
\text { Pemerintah }\end{array}$ \\
\hline & & $\begin{array}{l}\text { Nilai tukar } \\
\text { berpengaruh } \\
\text { negative } \\
\text { signifikan } \\
\text { terhadap } \\
\text { Imbal hasil } \\
\text { Obligasi } \\
\end{array}$ & 1. Hsing (2015) & $\begin{array}{l}\text { Determinants of the } \\
\text { Government Bond } \\
\text { Imbal hasil in Spain }\end{array}$ \\
\hline 4 & Likuiditas & $\begin{array}{l}\text { Berpengaruh } \\
\text { negative } \\
\text { signifikan } \\
\text { terhadap } \\
\text { Imbal hasil } \\
\text { Obligasi }\end{array}$ & $\begin{array}{l}\text { 1. Muharam } \\
\text { (2011) } \\
\text { 2. Jacobs, et al. } \\
(2011)\end{array}$ & $\begin{array}{l}\text { Model Determinan } \\
\text { Imbal Hasil Obligasi } \\
\text { Pemerintah }\end{array}$ \\
\hline
\end{tabular}


Tabel 1.1 Lanjutan

\begin{tabular}{|l|l|l|l|l|}
\hline & & $\begin{array}{l}\text { Berpengaruh } \\
\text { Positif } \\
\text { signifikan } \\
\text { terhadap } \\
\text { Imbal hasil } \\
\text { Obligasi }\end{array}$ & 1. Idham (2014) & $\begin{array}{l}\text { Analisis Faktor } \\
\text { Determinan yang } \\
\text { Mempengaruhi Imbal } \\
\text { hasil Obligasi Studi } \\
\text { empiris Pemerintah } \\
\text { Indonesia 2009) }\end{array}$ \\
\hline 5 & $\begin{array}{l}\text { Pertumbuha } \\
\text { n PDB }\end{array}$ & $\begin{array}{l}\text { Berpengaruh } \\
\text { Negative } \\
\text { signifikan } \\
\text { terhadap } \\
\text { Imbal hasil } \\
\text { Obligasi }\end{array}$ & $\begin{array}{l}\text { 1 Nurfauziah dan } \\
\text { Adistien (2004) }\end{array}$ & $\begin{array}{l}\text { Analisis Faktor-Faktor } \\
\text { yang mempengaruhi } \\
\text { Imbal hasil Obligasi } \\
\text { Perusahaan (Studi kasus } \\
\text { pada } \\
\text { perbankan dan industry } \\
\text { finansial) }\end{array}$ \\
\hline
\end{tabular}

Sumber : Ringkasan penulis (diolah)

\subsection{Rumusan Masalah}

Pemerintah melakukan reopening surat utang negara seri FR0031 pada awal bulan januari 2010 melalui sistem lelang Bank Indonesia. Tingkat bunga yang ditawarkan tetap sama seperti awal saat pemerintah menerbitkan surat utang negara seri FR0031 yaitu fixed rate sebesar 11\% akan tetapi dalam berjalannya waktu yield atau imbal hasil yang berbentuk kupon yang diterima oleh para investor berfluaktif bahkan tidak sampai menyentuh angka 11\%. Maka dari itu dalam penelitian ini akan dibahas mengenai pengaruh variabel-variabel yang dapat mempengaruhi besaran imbal hasil surat utang negara.

Uraian dalam latar belakang masalah di atas memberi dasar bagi peneliti untuk merumuskan pertanyaan penelitian yaitu:

1. Bagaimana pengaruh likuiditas terhadap imbal hasil surat utang negara seri FR $0031 ?$ 
2. Bagaimana pengaruh inflasi terhadap pergerakan imbal hasil surat utang negara seri FR 0031 ?

3. Bagaimana pengaruh BI rate terhadap pergerakan imbal hasil surat utang negara seri FR 0031 ?

4. Bagaimana pengaruh nilai tukar rupiah /dollarAS terhadap pergerakan imbal hasil surat utang negara seri FR 0031?

5. Bagaimana pengaruh produk domestik bruto perkapita riil terhadap imbal hasil surat utang negara seri FR 0031 ?

6. Bagaimana pengaruh likuiditas, inflasi, BI rate, nilai tukar rupiah/dollarAS dan produk domestik bruto perkapita riil secara simultan terhadap imbal hasil surat utang negara seri FR 0031 ?

7. Bagaimana perkembangan imbal hasil SUN FR 0031?

\subsection{Tujuan Dan Kegunaan Penelitian}

\subsubsection{Tujuan Penelitian}

Tujuan yang ingin dicapai dari penelitian ini ialah untuk :

1. Menganalisis pengaruh likuiditas terhadap imbal hasil surat utang negara seri FR 0031

2. Menganalisis pengaruh inflasi terhadap imbal hasil surat utang negara seri FR 0031

3. Menganalisis pengaruh BI rate terhadap imbal hasil surat utang negara seri FR 0031

4. Menganalisis pengaruh nilai tukar rupiah/dollarAS terhadap imbal hasil surat utang negara seri FR 0031 
5. Menganalisis pengaruh produk domestik bruto perkapita riil terhadap imbal hasil surat utang negara seri FR 0031

6. Menganalisis pengaruh likuiditas, inflasi, BI rate, nilai tukar rupiah/dollarAS dan produk domestik bruto perkapita riil secara simultan terhadap imbal hasil surta utang negara seri FR 0031

7. Menganalisis perkembangan imbal hasil di Indonesia.

\subsubsection{Kegunaan Penelitian}

Penelitian ini diharapkan dapat memberikan kontribusi :

1. Bagi pemerintah sebagai penerbit instrument obligasi negara diharapkan dengan adanya penelitian ini dapat memberikan masukan terkait faktor-faktor yang berpotensi mempengaruhi imbal hasil obligasi negara dan menjadi referensi dalam proses pengambilan kebijakan.

2. Bagi investor yang ingin berinvestasi pada obligasi negara diharapkan penelitian ini dapat memberikan gambaran mengenai imbal hasil, sehingga investor dapat memaksimalkan keuntungannya.

3. Hasil penelitian ini diharapkan dapat memberikan pengetahuan faktor-faktor yang mempengaruhi pergerakan imbal hasil di Indonesia, serta dapat menjadi rujukan akademis bagi penelitian yang berhubungan imbal hasil obligasi.

\subsection{Sistematika Penulisan}

\section{BAB I : Pendahuluan}

Bab ini berisi latar belakang masalah, rumusan masalah, tujuan dan kegunaan penelitian serta sistematika 


\section{BAB II : Tinjauan Pustaka}

Bab ini berisi teori-teori yang mendukung perumusan hipotesis, yang didukung dengan penelitian terdahulu. Kerangka pemikiran teoritis menjelaskan permasalahan yang akan diteliti yantu tentang apa yang seharusnya, sehingga timbul adanya hipotesis (dugaan awal penelitian)

\section{BAB III : Metode Penelitian}

Bab ini berisi metode penelitian akan diuraikan mengenai variabel penelitian, definisi operasional, jenis dan sumber data serta metode analisis yang digunakan dalam penelitian.

\section{BAB IV : Hasil dan Pembahasan}

Bab ini menjelaskan tentang analisis hasil penelitian, membahsa deskripsi statistik hasil pengolahan data, hasil pengujian hipotesis dan diskusi hasil uji aumsi klasik.

\section{BAB V : Penutup}

Bab ini merupakan bab terakhir yang menjelaskan kesimpulan, keterbatasan dan saran penelitian. 